\title{
Pendidikan Politik Bagi Masyarakat Kecamatan Samarinda Utara Di Kota Samarinda
}

\author{
Nur Hasanah*, Sry Reski Mulka, Hafizh Yudhistira Inderawaspada, Rudini \\ Program Studi Ilmu Pemerintahan, Fakultas Ilmu Sosial dan Ilmu Politik, Universitas \\ Mulawarman, Samarinda, Indonesia \\ Penulis Korespodensi: sryreskimulka@ fisip.unmul.ac.id
}

\begin{abstract}
ABSTRAK
Kegiatan Pengabdian Kepada Masyarakat yang dilaksanakan oleh Tim Pengabdian Program Studi S1 Ilmu Pemerintahan Fisipol Universitas Mulawarman. mengacu kepada pemberian sosialisasi dalam menyambut pesta demokrasi yaitu PILKADA SERENTAK 2020. Salah satu wilayah yang masuk kualifikasi partisipasi politik yang masih rendah ialah Kecamatan Samarinda Utara. Hal ini mengindikasikan bahwa telah terjadi apatisme di kalangan pemilih, di saat arus demokrasi dan kebebasan berpolitik masyarkat sedang marak-maraknya. Partisipasi politik menjadi salah satu kebutuhan agar keberlanjutan demokrasi dan sistem politik tidak mengalami hambatan. Dalam menyambut pemilihan kepala daerah 2020 mendatang, maka dapat dijadikan tolak ukur untuk menilai partisipasi masyarakat sebagai bagian dari proses Pendidikan politik yang baik. Semakin tinggi partisipasi menjadi nilai tersendiri akan penguatan proses Pendidikan politik, demikian sebaliknya. Upaya yang dapat dilakukan Tim Pengabdian Program Studi S1 Ilmu Pemerintahan Fisipol Universitas Mulawarman bekerjasama dengan Kecamatan Samarinda Utara dalam melaksanakan kegiatan pengabdian berupa pemberian Sosialisasi Pendidikan Politik kepada masyarakat Kecamatan Samarinda Utara. Sosialisasi dilaksanakan oleh Kesatuan Bangsa dan Politik berkolaborasi dengan Tim Pengabdian Program Studi S1 Ilmu Pemerintahan Fisipol Universitas Mulawarman berupa pemberian sosialisasi beserta materi Pendidikan politik kepada setiap masyarakat yang hadir.
\end{abstract}

Kata Kunci: Sosialisasi Pendidikan politik, Pendidikan politik, PILKADA SERENTAK 2020.

\section{PENDAHULUAN}

\section{Latar Belakang}

Kota Samarinda merupakan Ibukota Propinsi Kalimantan Timur yang memiliki 10 kecamatan yang terbagi atas 59 kelurahan. Kota Samarinda yang secara geografis utara berbatasan dengan Kecamatan Muara Badak dan Kutai Kartanegara, Timur berbatasan dengan Kecamatan Anggana dan Sanga-Sanga, Kabupaten Kutai Kartanegara, di bagian selatan berbatasan dengan Loa Janan dan Kabupaten Kutai Kartanegara, dan di bagian barat berbatasan dengan Kecamatan Loa Kulu dan Tenggarong Seberang, Kabupaten Kutai Kartanegara. Dari 10 kecamatan yang ada di Kota Samarinda, Kecamatan Samarinda Utara adalah kecamatan yang masih masuk dalam kualifikasi partisipasi politik yang masih rendah.

Jika ditinjau dari presentasi pemilih di Kota Samarinda pada pemilihan kepala daerah, terlihat bedasarkan hasil rekapitulasi hasil perhitungan suara pemilihan Wali Kota dan Wakil Walikota Samarinda tahun 2015 Model DA1-KWK hal 2-1 seperti jumlah DPT sekitar 26.757, yang mana partisipasi politik masyarakat dalam Pemilihan Walikota jumlah surat 
suara yang digunakan sekitar 12.393(46,\%) dan jumlah surat suara yang tidak digunakan (golput) sekitar 14.364 (54\%). Kemudian pemilihan Gubernur dan Wakil Gubernur propinsi Kalimantan Timur dapat dilihat dari angka golput mencapai 44,19 persen, dari data tersebut menjadi fakta bahwa masih rendahnya tingkat partisipasi politik masyarakat pada pemilihan Kepala Daerah.

Keadaan tersebut mengindikasikan bahwa telah terjadi apatisme di kalangan pemilih, di saat arus demokratisasi dan kebebasan berpolitik masyarakat sedang marak-maraknya. Tentunya potensi rendahnya partisipasi pemilih dalam pesta demokrasi nasional maupun lokal tersebut kiranya cukup mengkhawatirkan bagi perkembangan demokrasi yang berkualitas. Sebab tingginya resistensi terhadap partisipasi pemilih dapat berimplikasi melumpuhkan demokrasi, karena merosotnya kredibilitas kinerja partai politik sebagai mesin pembangkit partisipasi politik.

Menurut Miriam Budiarjo (2015:369) tingkat partisipasi yang rendah pada umumnya dianggap sebagai tanda yang kurang baik, karena dapat ditafsirkan bahwa banyak warga tidak menaruh perhatian terhadap masalah kenegaraan. Partisipasi politik menjadi salah satu kebutuhan agar keberlanjutan demokrasi dan sistem politik tidak mengalami hambatan. Pemilu sebagai instrumen utama demokrasi merupakan salah satu instrumen yang menjembatani suara rakyat sebagai pemilik kedaulatan untuk memberikan mandat kepada seseorang sebagai wakil rakyat atau sebagai penguasa yang akan duduk dalam pemerintahan. Tidaklah heran isu tinggi rendahnya angka partisipasi berkaitan dengan tingkat legitimasi dan kepercayaan warga kepada wakil mereka atau orang yang diberi mandat untuk menjalankan pemerintahan dan mengeluarkan kebijakan. Sebagai salah satu bagian dari keberlanjutan demokrasi, tingkat partisipasi pemilih juga akan berdampak pada siapa yang akan memenangkan pemilu dan mengatur kehidupan banyak orang. Sebagian negara-negara yang menganut demokrasi termasuk Indonesia menjadikan partisipasi sebagai salah satu agenda yang tidak dapat dikesampingkan dalam proses pemilu, khususnya dalam hal kehadiran atau tidaknya warga negara untuk memilih (voter turn out). Tujuan untuk mencapai pemilu yang demokratis itu dapat terlaksana dengan baik jika semua elemen turut ambil bagian untuk mencapainya.

Dalam momen pemilihan Kepala Daerah dapat dijadikan tolak ukur menilai partisipasi masyarakat sebagai bagian dari proses pendidikan politik yang baik. Semakin tinggi partisipasi menjadi nilai tersendiri akan penguatan proses pendidikan politik, demikian sebaliknya. Kantraprawira dalam (Affandi, 2012:33) memandang, pendidikan politik sebagai salah satu fungsi struktur politik dengan tujuan untuk meningkatkan pengetahuan politik rakyat agar mereka dapat berpartisipasi secara maksimal dalam sistem politiknya. Dalam perspektif ini, pendidikan politik merupakan metode untuk melibatkan rakyat dalam sistem politik melalui partisipasi dalam menyalurkan tuntutan dan dukungannya. Kota Samarinda telah melakukan upaya pendidikan politik untuk meningkatkan partisipasi politik, baik dalam bentuk sosialisasi yang dilakukan oleh Pemerintah Daerah dan Pemerintah Kecamatan sampai yang paling bawah yaitu Kelurahan, termasuk juga sosialisasi yang dilakukan oleh Komisi Pemilihan Umum Kota Samarinda, namun tentu perlu ada inovasi sehingga pendidikan politik ini tidak hanya dilakukan pada momentum tertentu saja akan tetapi perlu dilakukan secara kontinyu.

\section{Permasalahan Mitra}

Identifikasi Permasalahan:

a) Kurangnya pengetahuan dan pemahaman masyarakat khususnya tentang politik dan hak politik masyarakat. 
b) Masih rendahnya tingkat partisipasi pemilih dalam pemilihan Kepala Daerah.

c) Tidak adanya sarana pendidikan politik yang sifatnya kontinyu.

\section{Rumusan Masalah}

Berdasarkan identifikasi permasalahan di atas maka rumusan masalah dalam pengabdian ini adalah "Bagaimana upaya pendidikan politik bagi masyarakat Kecamatan Samarinda Utara di Kota Samarinda?".

\section{TINJAUAN LITERATUR}

Program Studi Ilmu Pemerintahan yang telah bekerja sama dan memberi kesempatan kepada Kecamatan Samarinda Utara dalam memberikan Pendidikan politik untuk masyarakat serta menyampaikan betapa pentingnya memberikan pemahaman tentang Pendidikan Politik bagi masyarakat, khususnya Ketika menjelang Pemilihan Kepala Daerah yang akan dilaksanakan di akhir tahun 2020 ini.

Materi yang disampaikan oleh beliau berfokus pada penyampaian sosialisasi Pemilu 2020. Sosialisasi disampaikan dengan tugas dan fungsi Kesbangpol serta pemahaman Pendidikan politik dan seputar Pemilu, Hasil Sosialisasi terbagi menjadi beberapa point, yaitu:

1. Definisi Pendidikan Politik

Definisi dan fungsi Pendidikan Politik. Beliau menyampaikan bahwa Pendidikan Politik adalah Proses Penurunan Nilai-nilai dan Norma-norma dasar dari Ideologi suatu Negara yang dilakukan dengan sadar, terorganisir, berencana, dan berlangsung secara berkelanjutan dari satu generasi ke generasi berikutnya dalam rangka Character Building (membangun watak/karakter) bangsa.

2. Fungsi Pendidikan Politik

Pemateri menyampaikan fungsi dari Pendidikan Politik adalah untuk memberikan isi dan arah serta pengertian kepada proses pengayatan nilai-nilai yang sedang berlangsung dengan menekan kepada usaha pemahaman tentang nilai-nilai yang etis normatif. Adapun Fungsi lainnya yaitu menanamkan nilai-nilai dan norma-norma yang merupakan landasan dan motivasi bangsa Indonesia serta dasar untuk membina dan mengembangkan diri guna ikut serta berperan dalam kehidupan pembangunan bangsa dan negara agar masyarakat kita turut merasa memiliki dan bertanggung jawab atas pembangunan bangsa.

3. Peran Serta Pemuda dalam Menguatkan dan Memajukan Demokrasi Masa Depan Ada 5 Peran Serta Pemuda dalam menguatkan dan memajukan Demokrasi masa depan, Peran tersebut adalah :

1) Pilar Penggerak

2) Pengawal jalannya reformasi dan pembangunan

3) Aktor untuk terwujudnya demokrasi politik dan ekonomi yang sebenarnya

4) Penuh Inspirasi

5) Sebagai Kelompok Penekan 
Diluar dari peran tersebut, ada 3 syarat bagi generasi muda yang ingin memajukan kualitas demokrasi di masa depan, yaitu

1) Moral perjuangan harus terpenuhi. Dalam hal ini generasi muda harus bebas dari kepentingan pribadi atau kelompok

2) Secara umum memiliki kesamaan pemikiran terkait dengan agenda yang diperjuangkan

3) Terlepasnya unsur-unsur primordialisme dalam perjuangan Bersama, karena hal ini merupakan hal yang sensitive dalam upaya mewujudkan kebersamaan

4. Tugas Badan Kesbangpol dalam Bidang Politik

Pemateri juga menyampaikan Tugas dan fungsi dari Badan Kesbangpol di bidang politik, yang mana adalah:

1) Mengumpulkan berbagai informasi, pemetaan situasi, kondisi, dan unsur-unsur yang mempengaruhi politik dalam negeri,

2) Meningkatkan pemahaman Demokrasi Partisipasi dan masyarakat,

3) Memfasilitasi pelaksanaan Pendidikan politik, etika dan budaya politik,

4) Menjalankan penyusunan Data dan informasi Partai Politik, Pelaksanaan Verifikasi bantuan keuangan Partai Politik,

5) Melaksanakan komunikasi politik, Dinamika politik, Verivikasi keberadaan partai politik, pemantauan pelaksanaan pemilihan umum DPR-RI, DPR Provinsi, DPRD, Presiden dan Wakil Presiden, Gubernur, Bupati, dan walikota

6) Memantau perkembangan Politik dalam Negeri dan Daerah

7) Ikut menjaga agar kegiatan pembinaan politik di daerah dapat berjalan bekelanjutan.

8) Badan Kesbangpol di daerah harus mampu memberikan masukan kepada pemerintah yang berada pada level-level diatasnya terkait perkembangan politik di daerahnya masing-masing dan kebutuhan Pendidikan politik untuk meningkatkan kualitas pelaksanaan pemilu, menjaga kondusifitas kamtibmas, dan semua hal yang mdibutuhkan dalam upaya ikut menciptakan kondisi kehidupan demokrasi yang sehat

9) Kesbangpol memberikan pemahaman kepada masyarakat dan generasi muda untuk memanfaatkan Lembaga-lembaga Perwakilan Daerah dan Pihak Eksekutif, sehingga peran dan control masyarakat tidak hanya berhenti saat Pemilu/kada selesai diadakan.

Adapun Tugas Kesbangpol kepada masyarakat adalah untuk meningkatkan Peran masyarakat dalam setuap tahapan Pemilu/Kada, diantaranya dalam hal :

1) Memberikan contoh kepada masyarakat di lingkungannya agar dating ke Tempat Pemungutan Suara (TPS) dan menyalurkan Hak Pilihnya pada Hari Pemungutan Suara

2) Ikut menjaga Netralitas PNS/ASN dan TNI/POLRI dalam setiap pelaksanaan PEMILU/PILKADA

3) Menjaga agar tidak terjadi Politik Uang di tengah-tengah masyarakat dan melaporkan jika ada temuan Politik Uang kepada Lembaga yang memiliki wewenang untuk menanganinya seperti Panwaslu dan Kepolisian, dan

4) Menanamkan kesadaran masyarakat untuk ikut serta berperan dalam menjaga keamanan dan ketertiban di lingkungannya masing-masing dari Ekses Gejolak Politik yang muncul selama Pilkada 2020. 
Masyarakat juga memiliki peran lainnya pada setiap Tahapan Pemilu/Pilkada, yaitu:

1) Ikut memantau Daftar Pemilih Tetap (DPT) dan memastikan seluruh warga di lingkungannya yang memiliki hak pilih mendapatkan surat undangan untuk dating ke TPS

2) Ikut aktif dalam memberikan penjelasan tentang pentingnya menggunakan hak pilih dengan dating ke TPS

3) Memantau keberadaan warga di luar DPT yang ikut mencoblos di TPS

4) Memberikan masukan/koreksi kepada panitia pemungutan suara di TPS berkaitan dengan prosedur dan teknis dalam menghadapi kondisi kerawanan yang mengganggu jalannya pemungutan suara, dan

5) Memberikan masukan dan koreksi tentang kondisi-kondisi lainnya yang memerlukan peran serta masyarakat di dalam upaya ikut memantau pelaksanaan pemungutan suara.

\section{Partisipasi Pemilih dalam Pesta Demokrasi}

Pemateri menyampaikan data tingkat partisipasi pemilih dalam pelaksanaan Pilgub di tahun 2018 yang berkisar 549.626 pemilih atau 58\%, dilanjutkan dengan pelaksanaan pileg dan pilpres di Tahun 2019 di Samarinda yaitu 72,20\% dengan total 449.177 Pemilih. Pilkada di tahun 2020 Bapak Kiswandi, S.K.M., M.Adm.Kes menargetkan $77 \%$ pemilih, yang mana di Tahun 2015 hanya mencapai $49 \%$.

Tahapan Pilkada Serentak sempat tertunda beberapa bulan karena adanya Penyebaran Wabah Virus Corona yang melanda di seluruh dunia, salah satunya di Indonesia. Melalui Rapat Dengar Pendapat Pemerintah Pusat, KPU dan DPR-RI menyimpulkan bahwa Tahapan Pilkada akan dilanjutkan pada 15 juni 2020 dan Pilkada resmi diundur pada 9 Desember 2020 yang sebelumnya jatuh pada 23 September 2020

6. Urgensi Partisipasi

Urgensi Partisipasi juga disampaikan dengan pemateri, ada 4 urgensi, yaitu:

1) Memilih dalam PEMILU merupakan Hak Asasi yang sangat penting dalam kehidupan Demokrasi

2) Besarnya Potensi Pemilih Muda akan meningkatkan Kader Pemilu

3) Melalui Partisipasi sebagai Pemilih, berarti ikut menentukan wajah-wajah Pemimpin yang akan mengelola Negara atau Daerah

4) Sebagai Pemilih Kritis, Pemilih Muda lebih Obyektif menentukan pilihan.

7. Pemilih Pemula

Pemilih Pemula merupakan Para Pelajar Sekolah Tingkat Atas yang umumnya duduk di kelas 3 (Tiga) atau sekarang disebut dengan kelas 12 adalah cikal bakal dan pemegang tongkat estafet kepemimpinan di Indonesia khususnya di Kalimantan Timur. Dengan demikian perannya juga sangat penting untuk menggunakan Hak Suara pada saatnya nanti, sebagai bentuk perkenalan pertama dalam Proses Politik. Bagi pemula dengan menggunakan Hak Pilih dalam pemilihan Walikota dan wakil walikota ini merupakan pengalaman pertama dan sejarah dalam hidupnya terlibat dalam menentukan Pemimpin yang pada akhirnya berdampak pada Pembangunan Nasional. Maka sangat disayangkan jika para pemula tidak memanfaatkan kesempatan untuk menggunakan Hak pilih pada Pemilu tahun ini, karena untuk mendapatkan kesempatan tersebut harus menunggu 17 tahun dan baru bisa digunakan setiap lima tahun sekali. Jumlah Pemilih Pemula di Kalimantan Timur 
mencapai 18.393 orang yang memiliki andil besar untuk menyukseskan Tingkat Partisipasi Pemilih. Karena itu diharapkan para khalayak anak muda bisa saling menyampaikan pentingnya satu suara dalam menentukan pemimpin dan arah pembangunan untuk [embangunan lima tahun kedepan melalui PILKADA SERENTAK 2020.

\section{METODE PELAKSANAAN}

Pada program pemberdayaan masyarakat dalam pendidikan politik ini memuat beberapa langkah kegiatan pemberdayaan, yaitu :

1. Melakukan identifikasi partisipasi masyarakat dalam kegiatan politik dan pemerintahan di Kecamatan Samarinda Utara.

2. Melaksanakan sosialisasi dan penyuluhan hak konstitusional masyarakat dan pentingnya partisipasi dalam politik.

3. Pendampingan/bimbingan terarah program sosialisasi dan penyuluhan pendidikan politik bagi masyarakat Kecamatan Samarinda Utara.

Kegiatan Sosialisasi Pendidikan Politik bagi Masyarakat Kecamatan Samarinda Utara di Kota Samarinda dilaksanakan di Aula Kecamatan Samarinda Utara pada Kamis, 15 Oktober 2020. Kegiatan Sosialisasi tersebut dihadiri oleh lebih kurang 25 peserta yang berasal dari perwakilan seluruh Kelurahan di Kecamatan Samarinda Utara dan Staf Kecamatan Samarinda Utara.

\section{HASIL DAN PEMBAHASAN}

(Pilkada) dan Nasional (Pilpres dan Pileg) sudah diatur dalam UU No. 10 Tahun 2016 Tentang pemilihan Gubernur dan Wakil Gubernur, Bupati dan Wakil Bupati dan/atau Walikota dan Wakil Walikota dan UU No. 7 Tahun 2017 Tentang Pemilihan Umum. Bahwa di dalam regulasi tersebut diatur tentang pengawasan partisipatif yang berasal dari masyarakat. tingkat partisipasi pemilih dalam pelaksanaan Pilgub di tahun 2018 yang berkisar 549.626 pemilih atau 58\%, dilanjutkan dengan pelaksanaan pileg dan pilpres di Tahun 2019 di Samarinda yaitu 72,20\% dengan total 449.177 Pemilih. Pilkada di tahun 2020 Bapak Kiswandi, S.K.M., M.Adm.Kes menargetkan 77\% pemilih, yang mana di Tahun 2015 hanya mencapai 49\%.Peran serta masyarakat sebgai pemilih dalam partisipasinya terhadap pemilu di akhir tahun ini akan sangat menentukan masa depan bangsa Indonesia terutama di Kota Samarinda. Pemateri juga menyerukan slogan yang berbunyi "Katakan Tidak pada Golput, Kampanye Hitam, Sara, Hoax, dan Politik uang, mari kita sukseskan pesta demokrasi dengan aman dan damai”.

\section{KESIMPULAN DAN SARAN}

Pengabdian Kepada Masyarakat yang dilakukan Program Studi S1 Ilmu Pemerintahan Fisipol Universitas Mulawarman dilakukan di Aula kecamatan Samarinda Utara di Kota Samarinda dengan melakukan upaya berupa memberikan sosialisasi Pendidikan Politik kepada masyarakat dalam rangka menyambut PILKADA Serentak diakhir tahun 2020 mendatang, Sosialisasi diberikan oleh pihak Kesbangpol yaitu Bapak Kiswandi, S.K.M., M.Adm.Kes selaku Kepala Bidang Politik, Sosialisasi yang diberikan dimulai dari Definisi dan fungsi dari Pendidikan Politik dan juga Tugas dan Fungsi dari Kesbangpol itu sendiri. Pada inti pembahasan, Kesbangpol membahas Peran Serta Pemuda dalam Menguatkan dan 
Memajukan Demokrasi Masa Depan, Partisipasi Pemilih dalam Pesta Demokrasi, urgensi partisipasi, dan pemilih pemula.

Adapun yang menjadi hambatan bagi Tim Pengabdian adalah waktu pelaksanaan terundur pada waktu yang sudah ditetapkan dikarenakan peserta banyak yang terlambat hadir dikarenakan terhambat cuaca yang tidak mendukung dengan derasnya hujan yang terjadi saat itu.Berdasarkan hasil kegiatan pengabdian yang telah dilaksanakan, maka saran yang dapat diberikan oleh Tim Pengabdian Program Studi S1 Ilmu Pemerintahan Fisipol Universitas Mulawarman adalah sebagai berikut:Pihak Kelurahan yang diundang hendaknya membawa masyarakat yang memang kurang memahami perpolitikan, maupun yang tingkat partisipasi politiknya masih kurang.

\section{DAFTAR PUSTAKA}

Affandi, I. (2012).Pendidikan Politik. Bandung: Mutiara Press.

Budiardjo, Miriam. 2015. Dasar-Dasar Ilmu Politik Cet.5. Jakarta.

Nurcholidah, L., Susanti, I., \& Kristiawati, I. (2018). PENGARUH REALISASI GROWTH RASIO PAD TERHADAP PERTUMBUHAN PEREKONOMIAN MASYARAKAT KABUPATEN LAMONGAN PERIODE TAHUN 2012-2016. JURNAL EKBIS: ANALISIS, PREDIKSI DAN INFORMASI, 19(1), 1011-1023.

Sari, Maria dkk. 2016. Pendekatan Ekonomi Wilayah dalam Perencanaan Pembangunan Kota Samarinda. Samarinda: Analisa

Syairozi, M. I. (2017). Percepatan Pengurangan Kemiskinan Sektor Pertanian di Kabupaten Malang. In Seminar Nasional \& Call For Paper, FEB Unikama (pp. 145-155).

\section{Sumber Internet:}

https://kaltimtoday.co/golput-masih-jadi-ancaman-pilkada-2020-kpu-samarindagencarkan-sosialisasi-untuk-kalangan-muda/ Diakses pada Hari Kamis, 2 Juli 2020 pukul 17.00 WITA. 